\title{
Recent advances on advanced oxidation process for sustainable water management
}

\author{
Lobna Mansouri $^{1}$ (D) $\cdot$ Salah Jellali ${ }^{1} \cdot$ Hanene Akrout $^{1}$ \\ Received: 18 March 2019 / Accepted: 15 April 2019 / Published online: 31 May 2019 \\ (C) Springer-Verlag GmbH Germany, part of Springer Nature 2019
}

\section{Foreword}

This topical collection of Environmental Science and Pollution Journal (ESPR) is dedicated to the third international conference on Advanced Oxidation Process for Sustainable Water Management (3rd AOP-Tunisia). It was held in Hammamet city, Tunisia, from 2nd to 4th of November 2017 and chaired by Prof. Latifa Bousselmi form the Centre for Water Research and Technologies (CERTE, www.certe. rnrt.tn). The main aim of this conference was to offer exchange opportunities between scientists, scholars, and socioeconomic actors operating in the domains of wastewaters treatment by advanced oxidation process and sustainable water resources management. It was also an excellent occasion to discuss on the latest research outputs regarding the cited above topics, to create new connections, to build new relationships, and to design future cooperation.

The 3rd AOP Tunisia conference was an international event, which was organized in terms of invited lecturers' contributions as well as refereed oral and poster presentations. An exhibition space gave the opportunity to companies to present their products and services. The conference was designed to cover four specific topic areas with seven identified Keynote speakers invited to address key issues in each topic area. The topic areas covered were (i) advanced oxidation process, (ii)

Responsible editor: Philippe Garrigues

Lobna Mansouri

lobna.mansouri@certe.rnrt.tn

Salah Jellali

lobna.mansouri@certe.rnrt.tn

Hanene Akrout

hanene.akrout@gmail.com

1 Wastewaters and Environment Laboratory, Centre for Water Research and Technologies, Technopark of Borj Cedria, Touristic Road of Soliman, BP 273, 8020 Soliman, Tunisia materials and engineering in AOP field, (iii) case study of AOP: implementation in industrial or urban context, and (iv) sustainable water management (approaches and tools, treatment, combination with AOP for water recycling).

This conference has attracted 109 abstracts from 11 different countries, covering three continents: Africa, Asia, and Europe. All these abstracts have undergone a formal peer-reviewed procedure in order to select the ones having excellent/good technical quality and to assign each one of them to the most adapted session. From these, only 87 abstracts were selected by the international scientific committee. There were 2 plenary communications, 7 keynotes, 33 full oral presentations, and 45 poster presentations. The total number of participants was 120 attendees. They came mainly from Tunisia (56\%), Jordan (12\%), Germany (11\%), and Algeria (11\%). The remaining $10 \%$ of participants were from France, Palestine, South Africa, Syria, Morocco, Sudan, and Nigeria.

After a meticulous peer-review process, nine (9) high scientific-level papers have been accepted for publication. They mainly concern wastewater treatment by photocatalysis, photo-Fenton, and adsorption technologies.

The first paper is entitled "Basic red 2 and methyl violet adsorption by date pits: adsorbent characterization, optimization by RSM and CCD, equilibrium and kinetic studies" (Wakkel et al. 2018). In this work the raw date pits as a low-cost agricultural waste has been studied in order to adsorb two cationic dyes (Basic red 2 (BR2) and methyl violet (MV)) from aqueous solutions. The authors used response surface methodology (RSM) for the optimization of the adsorption parameters (contact time, temperature, initial concentration of adsorbate, and $\mathrm{pH}$ ). Equilibrium isotherms were studied for BR2 and MV and their maximum adsorption capacities were 92 and $136 \mathrm{mg} \mathrm{g}^{-1}$, respectively.

The second paper "Combining micelle-clay sorption to solar photo-Fenton processes for domestic wastewater treatment" (Brienza et al. 2018) aims to study the water disinfection and emerging contaminants (ECs), mainly pharmaceuticals, removal from domestic wastewaters. It showed good performances of the filtration step in removing dissolved 
organic matter and all bacteria such as Escherichia coli and Enterococcus faecalis from the secondary treated water. Solar advanced oxidation processes presented high efficiency in the elimination of trace levels of ECs. The final treated effluent presented acceptable chemical and biological characteristics for irrigation.

The third accepted paper "Comparative study of Gramnegative bacteria response to solar photocatalytic inactivation" (Achouri et al. 2018) studied the kinetic modeling of solar photocatalytic inactivation of Gram-negative bacteria with immobilized $\mathrm{TiO}_{2}-\mathrm{P} 25$ in a fixed-bed reactor. The results showed different responses of the bacteria strains to photocatalytic stress and the ability of certain bacterial strains such as Escherichia coli ATCC25922 and Pseudomonas aeruginosa ATCC4114 to resuscitate after photocatalytic treatment.

The fourth paper is entitled "Application of direct contact membrane distillation for saline dairy effluent treatment: performance and fouling analysis" (Abdelkader et al. 2018). It consisted in studying saline dairy effluent (discharged from hard cheese industry pretreatment) by direct contact membrane distillation (DCMD) after macrofiltration (MAF) or ultrafiltration (UF) pretreatment. The results indicated that effluents pretreated by UF have led to the best DCMD process performance with stable flux values at different operating conditions. In all experiments, the permeate has maintained a good quality with low electrical conductivity and low total organic carbon $(<2 \mathrm{mg} / \mathrm{L})$.

The fifth paper "Photodegradation using $\mathrm{TiO}_{2}$-activated borosilicate tubes" (Khalaf et al. 2018) confirmed that the use of $\mathrm{TiO}_{2}$ supported on borosilicate tubes appears to be a promising alternative for the organic pollutants' removal compared with conventional $\mathrm{TiO}_{2}$ suspension and avoiding postseparation stages. The authors suggested that the obtained results could be used to optimize large-scale applications, and expand the study to cover a wide range of persistent organic pollutants (POPs) from water.

Concerning the sixth paper which is entitled "Process optimization via response surface methodology in the physicochemical treatment of vegetable oil refinery wastewater" (Louhıch et al. 2018), the authors developed an optimization work on the coagulation/flocculation process using aluminum sulfate as coagulant and CHT (industrial flocculent) as coagulant aid/flocculent in the treatment of vegetable oil refinery wastewater. The results showed good agreement between experimental results and prediction models, ensuring a satisfactory adjustment of the second-order regression model with the experimental data.

Regarding the seventh paper "Photocatalytic treatment of petroleum industry wastewater using recirculating annular reactor: comparison of experimental and modeling" (Rabahi et al. 2018), it was proven that the elimination of petroleum pollutants by applying heterogeneous photocatalytic process was efficient reaching 76.19 and $79.55 \%$ in the binary (toluene/benzene) and the ternary mixtures (toluene/benzene/ xylene), respectively. Furthermore, a well-fitting between theoretical value and the experimental data has been reported.

The eighth paper "Effects of short-and long-term exposure of humic acid on the anammox activity and microbial community" (Kraiem et al. 2018) studied the humic acid effects on the Anammox process. This work showed that the Anammox activity was strongly affected by the presence of humic acid (> $70 \mathrm{mg} / \mathrm{L}$ ). However, humic acid, used as carbon source by heterotrophic bacteria, has promoted heterotrophic denitrifying bacteria which became dominant in the reactor. Thus, its presence should be controlled in the influent in order to avoid Anammox activity inhibition.

The last paper "Steady-state modeling of the biodegradation performance of a multistage moving bed biofilm reactor (MBBR) used for on-site greywater treatment" (MasmoudiJabri et al. 2018) illustrated that a good match was found between the simulated activated sludge model (ASM3) to a full-scale multistage MBBR and the experimental results for the treatment of gray water.

The Guest Editors of this special issue are thankful to all the authors for their innovative contribution and also to the reviewers for their constructive comments and suggestions that highly contributed to the improvement of the scientific quality of the accepted papers. Big thanks to the German Academic Exchange Service (DAAD), the COMSATS organization, the French Institute in Tunisia (IFT), and the six Tunisian companies (Analytica, Sky Distribution, Remington, SITEX, Varta, Eschams Company) for their supports.

We would like also to thank ESPR Editor-in-Chief Philippe GARRIGUES and the editorial assistant Fanny CREUSOT for their assistance and important support in the preparation of this special issue.

\section{References}

Abdelkader S, Gross F, Winter D, Went J, Koschikowski J, Geissen SU, Bousselmi L (2018), Application of direct contact membrane distillation for saline dairy effluent treatment: performance and fouling analysis. Environmental Science and Pollution Research, https://doi. org/10.1007/s11356-018-2475-3

Achouri F, BenSaid M, Bousselmi L, Corbel S, Schneider R, Ghrabi A (2018), Comparative study of Gram-negative bacteria response to solar photocatalytic inactivation. Environ Sci Pollut Res, https://doi. org/10.1007/s11356-018-2435-y

Brienza M, Nir S, Plantard G, Goetz V, Chiron S (2018), Combining micelle-clay sorption to solar photo-Fenton processes for domestic wastewater treatment. Environmental Science and Pollution Research, XX, YY-ZZ, https://doi.org/10.1007/s11356-018-2491-3

Khalaf S, Shoqeir J H, Scrano L, Karaman R, Bufo Sabino A (2018) Photodegradation using $\mathrm{TiO}_{2}$-activated borosilicate tubes. Environmental Science and Pollution Research, https://doi.org/10. 1007/s11356-018-2858-5 
Kraiem K, Wahab MA, Kallali H, Fra-vazquez A, Pedrouso A, Mosquera-Corral A, Jedidi N (2018) Effects of short- and longterm exposures of humic acid on the Anammox activity and microbial community. Environ Sci Pollut Res, https://doi.org/10.1007/ s11356-018-2786-4

Louhıchı G, Latifa Bousselmı L, Ghrabı A, Khounı I (2018) Process optimization via response surface methodology in the physicochemical treatment of vegetable oil refinery wastewater. Environ Sci Pollut Res, https://doi.org/10.1007/s11356-018-2657-z

Masmoudi- Jabri K, Fiedler T, Saidi A, Nodleerwin N, Ogurek M, Geissen SU, Bousselmi L (2018) Steady-state modeling of the biodegradation performance of a multistage moving bed biofilm reactor (MBBR) used for on-site greywater treatment. Environmental Science and Pollution Research, https://doi.org/10.1007/s11356018-3984-9

Rabahi A, Assadi AA, Nasrallah N, Bouzaza A, R Maachi R, Wolbert D (2018) Photocatalytic treatment of petroleum industry wastewater using recirculating annular reactor: comparison of experimental and modeling. Environmental Science and Pollution Research, https://doi.org/10.1007/s11356-018-2954-6

Wakkel M, Khiari B, Zagrouba F (2018), Basic red 2 and methyl violet adsorption by date pits: adsorbent characterization, optimization by RSM and CCD, equilibrium and kinetic studies. Environ Sci Pollut Res, https://doi.org/10.1007/s11356-018-2192-y

Publisher's note Springer Nature remains neutral with regard to jurisdictional claims in published maps and institutional affiliations. involved in several European projects and the organization of several international conferences and workshops.

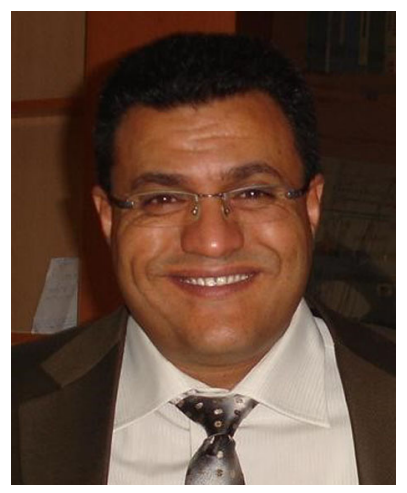

Salah Jellali Editor of the special issue AOP-Tunisia. Salah Jellali serves as a full professor in sciences and engineering for water at the Wastewaters and Environment Laboratory of the Wat e r R e s e a $\mathrm{c} \mathrm{h}$ a n d Technologies Centre (CERTE), Tunisia. He obtained a dual engineering diploma from the high school of rural equipment of Medjez El Bab (Tunisia) and from the national school for water and environmental engineering, Strasbourg, France, and M.S (1996) and Ph.D. (2000) degrees in Water and Engineering for water from the University of Strasbourg. After a postdoctoral position and a brief experience in BURGEAP, Strasbourg, he returned home to begin an academic position as assistant, associate, and full professor at CERTE. His research interests include wastewaters treatment by low-cost materials, nutrients recovery from wastewaters and reuse in agriculture, local water management, and groundwater flow and pollutants' transport modeling for a sustainable management. Prof. Jellali has published more than 40 papers in impacted referred journals. He participated to the organization of various international congresses dealing with water/ wastewaters management.

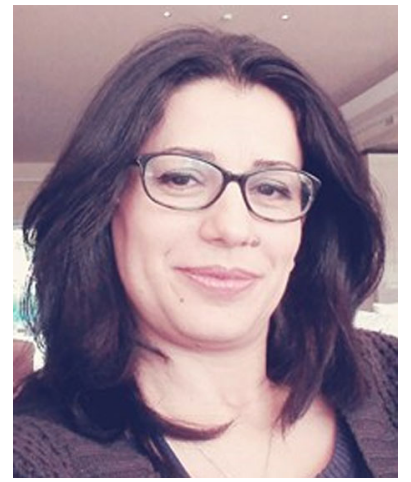

Hanene Akrout Editor of the special issue AOP-Tunisia. Hanene Akrout obtained her Ph.D. in Electrochemistry from University of Science of Tunis (FST), Tunisia, and National Institute of Polytechnics of Grenoble (INPG), France. She is an associate professor in Water Research and Technologies Centre CERTE from 2016. Her expertise developed in wastewaters \& environment laboratory of CERTE focused on environmental electrochemistry and related material development essentially metal/wastewaters interfaces. She has contributed strongly in the implementation of several national research programs. All these projects are related to the development of electrochemical treatment applied to different quality of industrial wastewaters for reuse and valorization. In this context, she has ensured the supervision of an important number of Engineer, Master, and Ph.D. students. Dr. Akrout has published 25 papers in impacted referred journals. She was also involved in European projects and the organization and member of scientific committee in several international conferences. 